\title{
Cyberbullying in Polish Debate on the Białowieża National Forest
}

\author{
Aleksandra Matulewska ${ }^{1} \cdot$ Joanna Kic-Drgas $^{1} \cdot$ Paula Trzaskawka $^{1}$
}

Published online: 11 July 2020

(c) The Author(s) 2020

\begin{abstract}
Social media platforms have conquered almost all fields of human life; their impact as opinion creating tools is undisputable. They not only offer a place for people to exchange experiences, but are also a virtual space where people fight with words in defence of their beliefs. This second function has made social media a rich source for linguistic analysis, providing material for the most current social, political, and economic issues. The main aim of this paper is to contribute to reducing the identified gap in the literature on hate speech and consequential cyberbullying from the linguistic perspective and provide conclusions on elements of hate speech through the analysis of statements relating to the cut-out of the Białowieża National Forest. The examples were excerpted from the Polish social media websites of activists representing two opponent groups. This paper consists of three parts. The first part provides an overview of the literature related to hate speech, cyberbullying, their definitions, roles, and the possibilities of analysis. In this part, the background of the discussed polemic is also highlighted (the geographic location of the Białowieża National Forest, arguments used by both sides of the conflict etc.). The second part of the paper presents and discusses the results of the conducted research. After having examined some of the social media platforms used by the groups representing different attitudes to the described conflict (including Facebook, Twitter etc.), we have identified linguistic patterns within aggressive and vulgar statements expressed both directly and indirectly. Therefore, our analysis concentrates on categorisation of characteristic elements of hate statements. In the third part of the paper, we present conclusions referring to the results of the analysis.
\end{abstract}

Keywords Hate speech · Cyberbullying · Białowieża National Forest · Social media $\cdot$ Linguistic perspective

Paula Trzaskawka

paula.trzaskawka@amu.edu.pl

Extended author information available on the last page of the article 


\section{Introduction}

The aim of the paper is to analyse the phenomenon of cyberbullying and its main focus is on the empirical analysis through the analysis of statements occurring in the polemics about the cut-out of the Białowieża National Forest in Poland.

First, the emergence and role of social media in modern societies are discussed in order to highlight their importance in opinion building process and triggering certain actions (like in case of cyberbullying). Second, the phenomenon of cyberbullying and its legal status as a crime in Poland is briefly presented with an attempt to delineate its definition and pinpoint in which cases of the discussed hate speech acts criminal proceedings have been initiated in Poland. Third, hate speech characteristics is succinctly provided from different perspectives (linguistic, legal, social). The research part of the paper contains the analysis of examples of messages containing linguistic markers which enable to classify them as hate speech or other acts of verbal aggression or cyberbullying. In order to provide some insight into the problem, a controversial topic of the conservation of the Białowieża National Forest in Poland is presented. The supporters of naturalness of the forest protest against killing the insect (bark beetle) and removing the infected trees, whereas the foresters fight for the permission to remove the trees to stop the degradation of the forest. The issue has turned out to be so controversial, that the decision had to be made at the European Union level. The conflict started about 2008 and is still present on the media as the degradation of the forest that has followed right now causes huge risks due to collapsing trees and potential fires.

\section{Research Methods, Materials and Hypothesis}

The research methods applied by the authors include the following:

1. The corpus analysis (corpus will be discussed below),

2. The terminological analysis of the research material (empirical observation),

3. The analysis of pertinent literature.

The authors have extracted the examples from the main sources of social media that is to say:

1. Twitter,

2. Facebook,

as well as:

1. “Puszcza Białowieska” Blog [Białowieża Forest Blog],

2. An article from a website and comments to it. 
The media have been selected on the basis of their popularity in Poland and the most frequently Googled sites devoted to the Białowieża National Forest conflict.

The authors took into consideration Twitter as the first source of negative comments concerning the conflict in Białowieża National Forest (in Polish: Puszcza Białowieska). Firstly, one have to illustrate what Twitter is about. This social platform consists of tweets-short comments about up-to-date issues. Also, what is important, users of Twitter use hashtags which help to find a topic of interest. In our research we have monitored \#puszczabialowieska and analysed all available tweets and comments with this particular hashtag (near 500 entries) posted since 6th March 2014. The conflict started earlier but the history of this hashtag on tweeter is no older than 2014. As mentioned before, the authors of this paper analysed all tweets and comments between the period of 2014 and January 2020. The number of tweets which could be assigned as an example of hate speech were 108 (according to Nijakowski's classification, explained below). The main criterion was the hate factor treated as an introduction to undertake further actions. Statements using only curse words were classified as offensive but not triggering further actions. The character and length of the tweets and comments differed but as it is a common knowledge tweets cannot be longer than 280 characters. What is more, to enter, comment and retweet one needs to create an account on Twitter.

Facebook, as the second example of social media, has been taken into account as a source of hate speech and cyberbullying on the topic of Białowieża National Forest. The best source of finding examples on cyberbullying and hate speech is the discussion panel which was introduced to the platform a few years ago. The authors analysed the discussion panel called Puszcza Białowieska [Białowieża National Forest]. The oldest post comes from 27th January 2016 and the newest form 1st January 2020. We analysed about 100 out of which 65 were analysed in detail. Those 65 were chosen as they were the examples of cyberbullying meeting the adopted criteria to the greatest extent. It should be stressed that the comments and posts can be moderated on Facebook. The number of examples with hate speech is not very high as the author of the particular post may block commenting when improper speech appears. One can block a person who assaults others or makes improper comments. Furthermore, we should remember that comments are our main source of the analysis as they represent the vast majority of different opinions about a given topic.

The third medium that we took into account was a blog devoted only to Białowieża National Forest [Puszcza Białowieska]. There, the author of the blog may moderate and control what other people say about topics concerning Białowieża National Forest. It is visible that the author of the blog does not agree to post every comment or one can even find comments which are in grey saying that the comments were deleted by the author of the blog. This blog is the biggest source of our analysis as its origins begin in 2008. We analysed posts from 2010 to 2011 and 2016 to 2018. We took into consideration those two periods as the first one represents the main conflict period with two sides and the second period when it was discovered that one side was wrong from the beginning and the second was right. In 2010 there were 199 posts with comments, 2011-154, 2016 - 130, 2017-105 and 2018 - 74. We can distinguish there three types of comments based on length: 
1. One-verse,

2. Paragraph,

3. Eaborate - the content of a comment is longer than the blog post-more than two paragraphs.

Some posts have typical mems that offend the late Minister of the Environment Professor Jan Szyszko. Often, these are sentences out of context that only exacerbate conflict atmosphere.

The last source for our corpus were comments to the article: Las Bawarski jak Białowieża. "Hodujesz korniki, ty świnio" [Bavarian Forest like Białowieża. "You grow bark beetles, you pig"]. This article was posted on a popular Polish portal wp.pl in October 2017. It includes 220 comments among which 17 were found offensive (using very offensive language) and included into our analysis.

The authors put forward the following research hypothesis: the environment related blog discussions frequently turn into an aggressive discourse, and even into hate speech because interlocutors represent two groups: (i) foresters with narrow field-education and (ii) persons with very different educational backgrounds, who are interested in environmental issues and feel specialists but very often have limited knowledge and cannot use substantive arguments based on scientific research.

Furthermore, the authors would like to stress that this topic has not been investigated in Poland. There are only two papers devoted to a similar topic that is to say the cyberbullying of hunters $[1,2]$.

\section{Social Media and Modern Society}

Social media is a complex modern phenomenon related to diverse social and technological processes. Baruah [3] highlights that "the term Social Media refers to the use of web-based and mobile technologies to turn communication into an interactive dialogue". However, Boyd and Ellison [4] define social network sites as "web-based services that allow individuals to:

1. Construct a public or semi-public profile within a bounded system,

2. Articulate a list of other users with whom they share a connection, and

3. View and traverse their list of connections Social Media, Politics and the State and those made by others within the system."

Clearly, the three forms of modern sociability (cognition, communication, cooperation) are incorporated into the definition above, becoming the vital part of social media existence and functioning. According to the presented approach, individuals possess a certain cognitive feature enabling them to interact through the shaping of opinions, ideas and concepts in common spaces. The mentioned spaces are used not only to interact but also to co-create/co-produce new qualities through knowledge integration and construction. Since social media networking sites like Twitter and Facebook have gained popularity as key tools for news, journalists and their 
organizations, these sites have become a part of many people's day-to-day routines. They can be characterised by two important features. First, they require some form of participation; even if social networking sites such as Facebook allow passive viewing of what others are posting, at least a profile must be created that can be treated as triggering the potential for active participation. Second, social media involves some interaction. This interaction can be established with friends, family, or acquaintances, or with new people who share common interests or even a common acquaintance circle [5]. It is worth mentioning that the rapid development of social media has contributed to the strengthening of certain processes: integration, time effectiveness, least effort and orderliness. Especially in terms of integration, social media platforms play an important role of unifying many users dispersed worldwide and provide them access to heterogeneous information resources. At the same time, all information is sent and received immediately, which enables information exchange synchronization. As the access to social media is generally free, these platforms are meant to help their potential users put in minimal effort to get and utilize the information, which is the driver of social media. Finally, due to the users' ability to edit and revise information, false and useless information on social media can be filtered out [6]. At the same time, fake news is present on the Internet as well.

Social media can take different forms. These include blogs, micro-blogs, wikis, social networking sites, photo-sharing sites, instant messaging, video-sharing sites, podcasts, widgets, and virtual worlds [7]. The existence of such a wide array of opportunities for interaction has led to the rapid increase in social media usage.

On the positive side, social media platforms such as blogs, social networking sites (e.g. Facebook) and instant messaging platforms (e.g. WhatsApp) are highly beneficial in terms of digital communication. They make almost constant interaction possible while simultaneously offering the opportunity to establish new contact with other users worldwide [8]. On the negative side, the freedom and anonymity experienced online makes users feel vulnerable in threatening situations including grooming or sexually transgressive behaviour, signals of depression and suicidal thoughts, and cyberbullying [8].

The reason for the mentioned negative behaviour patterns can be explained by the fact that as individuals can select the information they receive online, they believe they are surrounded by more like-minded people online than in real-world contexts, which leads to the decreased fear of isolation. Individuals thus feel free to express their opinions online, minimizing the so-called spiral of silence ${ }^{1}$ [10] effect on the Internet [9]. Other early critics draw attention to two more aspects of the Internet that can reduce the spiral of silence effect: the anonymity and lack of interpersonal presence [11]. Over time, Facebook and Twitter, instead of becoming places of open-mindedness, have become the ring for fights between opponents who represent different views and beliefs.

\footnotetext{
1 The spiral of silence is the fear of social isolation, which is a fundamental part of the public opinion process. "Spiral of Silence Theory proposes that what individuals perceive as the climate of opinion will shape their willingness to speak out, and in turn will influence the perception of others and their willingness to express one's own views." [9].
} 
The anonymity of the actions taken on the Internet has also become the main factor in the abuse of freedom of speech. One of the potential risks of relying on online technologies is cyberbullying, which is considered to be one of the major examples of technology abuse in the past decade due to the negative and sometimes even deadly effects it has on its victims [12].

\section{Offence, Hate Speech and Cyberbullying}

The distinction between the expressions (offence, hate speech and cyberbullying) is very blurred. The problem in defining them unequivocally stems, first of all, from the fact that the phenomena modified in the recent time (due to digitalization) have not yet been studied in depth, and that they are influenced by the individual character of the human being, one's worldview and cultural factors, which is even more profound due to the ambiguous character of the terms. For the purposes of this article, the following distinction has been adopted.

To present the complexity of the term hate speech let us look at a few definitions. One of them states that it is the type of "public speech that expresses hate or encourages violence towards a person or group based on something such as race, religion, sex, or sexual orientation" [13]. When we talk about public speech we think not only about presentations made publicly in front of other people, among peers, etc. but also those we post on the Internet. It is much easier as the Internet provides us anonymity and gives us self-confidence in expressing our thoughts because we cannot be judged as our face may be not recognisable, we can be a simple avatar or even a no name or random Jon Doe, or even we can change names constantly to hide the track. Moreover, hate speech is "usually thought to include communications of animosity or disparagement of an individual or a group on account of a group characteristic such as race, colour, national origin, sex, disability, religion, or sexual orientation" [14]. The term hate speech is being debatable in many countries around the world as well as it is the object of legislation-where the freedom of speech ends and hate speech begins to occur. It is a well-known fact that in some countries hate speech is not a legal term [15]. In Poland laws punish those who offend the feelings of the religious by e.g. disturbing a religious ceremony or creating public calumny. They also prohibit public expression that insults a person or a group on account of national, ethnic, racial, or religious affiliation or the lack of a religious affiliation [16]. Though, such lawsuits must be instigated in the majority of cases by victims. Moreover, the definition of hate speech as a new phenomenon both linguistically and socially funded evokes many controversies among researchers that lead to inconsistencies in formulating its definition. According to the Council of Europe's Committee of Ministers Recommendation 97(20), hate speech is defined as follows:

the term "hate speech" shall be understood as covering all forms of expression which spread, incite, promote or justify racial hatred, xenophobia, antisemitism or other forms of hatred based on intolerance, including: intolerance expressed by aggressive nationalism and ethnocentrism, discrimination and hostility against minorities, migrants and people of immigrant origin. 
In the definition, the spreading, incitement, promotion or justification of actions of harassment, leading to racial hatred, xenophobia, antisemitism or other forms of intolerance and hatred are explicitly classified as hate speech. The participants of the RADAR project opt for defining hate speech as "a kind of symbolic (verbal and nonverbal violence) discriminatory communication the aim of which is to humiliate a representative of an ethnic or national minority other than our own. It expresses disdain, hatred and prejudice" [17], emphasising in this way the existence of two or more parties which are in a state of conflict.

Weber [18] highlights that hate speech can refer to a multiplicity of situations:

1. Incitement of racial hatred directed against persons or groups of persons on the grounds of belonging to a race;

2. Incitement to hatred on religious grounds, on the basis of a distinction between believers and non-believers;

3. And lastly, to use the wording of the Recommendation on "hate speech" of the Committee of Ministers of the Council of Europe, incitement to other forms of hatred based on intolerance "expressed by aggressive nationalism and ethnocentrism".

The examples shown below demonstrate that hate speech, as a relatively new phenomenon that is accompanying the development of social media can be defined in various ways. For the needs of this paper, the authors have decided to describe hate speech as any form of statement that encourages hatred and violent behaviours towards any conceivable social group.

The following indicators proposed by Nijakowski [19] are helpful in assessing whether we are dealing with hate speech:

1. The excessive generalization of a negative trait-negative stereotypes of foreign groups;

2. The attribution of particularly negative traits - attribution to individuals or groups particularly negative qualities or deeds;

3. The offensive vocabulary, dehumanization — analogies, metaphors;

4. The disregard, questioning the custom of respect-patronising treatment, to show superiority, not to speak;

5. The catalogues and lists-catalogues exposing "Jews";

6. The object of hatred-hate speech stigmatises the object of criticism or social groups, of which membership is not a matter of choice (race, sexual orientation, nationality, ethnic origin, etc.).

When it comes to cyberbullying it is worth mentioning some background history and some definitions at first. Cyberbullying is a form of bullying or harassment effected via electronic means. Sometimes it is called online bullying. This type of behaviour includes posting rumours, threats, sexual remarks, revealing the victim's personal information, or pejorative labels including hate speech (cf. definition of cyberbullying in the US legal system [20]). The type of cyberbullying which will 
be examined in our research is Internet trolling which is a common form of bullying over the Internet in an online community, e.g. social media (the authors took into consideration Twitter and Facebook) in order to evoke a reaction, disruption, someone's own personal amusement or even attention of the public (cf. [21, 22]). It is said that there are many risks attached to social media sites, and cyberbullying is one of the larger risks (cf. [23]). Such an example is the topic of the Białowieża National Forest - a piece of National Heritage in Poland. There are many examples that the topic of the Białowieża National Forest conservation leads to the outburst of hate speech in social media. Moreover, "Cyberbullying can also take place through the use of websites belonging to certain groups to effectively request the targeting of another individual or group. An example of this is the bullying of climate scientists and activists" (cf. [24-26]). Moreover, National Crime Prevention Council says that "Cyberbullying is similar to other types of bullying, except it takes place online and through text messages sent to cell phones" [27]. Furthermore, "The definitions of internet aggression vary across studies. Typically, it is defined as 'overt, intentional acts of aggression toward others online' [28]. Cyberbullying is another name for internet aggression, which includes specific behaviours such as rude, embarrassing, threatening, or harassing comments, unwanted sexual comments, and exclusion (cf. [29, 30])." [31]

When talking about cyberbullying in Poland we should discuss the legal background of this phenomena. One amendment to the Act concerning cyberbullyingPolish Criminal Code-entered into force on 6th June 2011. It was published in the Polish Journal of Laws of 2011 no. 72, item 381, recognizing cyberbullying and stalking as a criminal offence. Currently, this offence is punishable under article 190a of Polish Criminal Code [32, 33] and it includes the following actions:

- Paragraph 1: Who by persistent harassment of another person or a loved one raises in them a feeling of threat justified by the circumstances or significantly violates his privacy, shall be punishable by imprisonment of up to 3 years.

- Paragraph 2: Whoever is impersonating another person, uses his or her image or other personal data to cause material or personal damage.

- Paragraph 3: If the consequence of an act specified in para. 1 or 2 is the victim's tapping into his own life, the perpetrator shall be subject to imprisonment for a term of between 1 and 10 years.

- Paragraph 4: Prosecution of the offense specified in para. 1 or 2 shall take place at the request of the injured party.

The insertion of art. 190a to the Polish Criminal Code ended the period of impunity for people using the Internet to harass other people. Notwithstanding this regulation, they remain punishable also for libel, insult, criminal threat, destruction of IT data and obstructing access to IT data, which may be an aspect of cyberbullying. Regardless of the criminal law protection of the victim, such a person may additionally sue the persecutor in a civil trial, e.g. for infringement of personal rights.

To sum up, cyberbullying in reference to our paper "refers to any harassment that occurs via the Internet, cell phones or other devices. Communication technology is used to intentionally harm others through hostile behaviour such as sending text 
messages and posting ugly comments on the Internet"2 [34]. In our research material we used mostly comments to posts concerning the Białowieża National Forest on such social media such as Facebook or Twitter as well as blogs about the discussed topic.

\section{The Białowieża National Forest: The Specificity of the Region, Origins of the Conflict, Involved Parties, and Their Arguments}

The Białowieża National Forest is a preserved forest complex with fragments of the primeval forest located between Poland and Belarus. The old forest stretches from Europe's Atlantic coast to the Ural Mountains, with a total area of 150,582 hectares, $59 \%$ of which is on the Belarusian side ( 87,363 ha) and the rest $(41 \%$ or 62,219 ha) in Poland [35].

The Białowieża National Forest has been shortlisted as a national UNESCO heritage site for two main reasons [36]:

1. The Białowieża National Forest conserves a diverse complex of protected forest ecosystems that exemplify the Central European mixed forest terrestrial ecoregion. It also contains a range of associated non-forest habitats, including meadows, river valleys and other wetlands. The area has an exceptionally high nature conservation value. On top of that, the large and integral forest area supports complete food webs including viable populations of large mammals and large carnivores such as the wolf and lynx.

2. The Białowieża National Forest is an irreplaceable area for biodiversity conservation particularly due to its size, protection status and substantially undisturbed nature. The property is the natural habitat of the largest free-roaming population of European bison. The biodiversity conservation values are extensive and include protection of 59 mammal species, over 250 bird species, 13 amphibian species, 7 reptile species, and over 12,000 invertebrates.

The conflict started about 2008. In 2009 the Laboratory for All Living Beings ${ }^{3}$ [Pracownia na rzecz. Wszystkich Istot] was recognized as a party in conflict over the Białowieża National Forest. As a result of protests of the organisation the infected trees were left in the forest. The scale of forest degradation has turned out to be massive. In 2017 a serious conflict between ecologists and foresters occurred again in the Białowieża National Forest caused by intensive tree felling, which the Ministry

\footnotetext{
2 Moreover, the term offence, or to be more precise, offensive language means the use of uncensored expressions, but it does not yet induce any action, whereas if it induces an action it is hate speech that can lead to cyberbullying if committed on the Internet. Hate speech can be uttered on paper, or in the form of oral statements which then can by classified as instanced of bullying but not cyberbullying (because they are not perpetrated on the Internet).

${ }^{3}$ It is an organisation which states that its aim is to take care for the high quality of the natural and cultural environment and act on behalf of all beings_-both nature and people. Official website https://praco wnia.org.pl/o-pracowni/o-nas Accessed on 15 June 2020.
} 
of the Environment claimed was used to stop the European spruce bark beetle, and protesting ecologists claimed to be commercial in nature.

In April 2017, the European Commission gave Poland thirty days to respond to allegations of violations of EU environmental directives. The government indicated that cutting down trees does not contradict Poland's obligations under the Birds and Habitats Directives, as the Białowieża National Forest is threatened by bark beetles, and that the problem is actually "the constant pressure from naturalists-radical environmentalists" [37].

The European Commission appealed against Poland to the Court of Justice of the European Union, pointing out that the felling was a serious threat to the integrity of the Natura 2000 area, was not consistent with the protection objectives of the Białowieża Primeval Forest, and exceeded the measures that can be used to ensure the sustainable use of the forest [37].

The main arguments used by the opponents are contrasted in Table 1.

\section{Discussion}

Here, the authors would like to present some comments ${ }^{4}$ from the blog about Białowieża National Forest and some other social media accounts. All of them represent different types of hate or offensive speech according to the classification of hate speech based on the group of initiators [38].

The first of these groups are people convinced of their superiority over other people, believing in social divisions, the need for domination or the superiority of one group over another, and they are thus compelled to make the weaker group submit to the dominant one. To the group belongs people of a dominant nature who successively and effectively eliminate weaker opponents.

\subsection{Example No. 1}

$\mathrm{X}$ : "Who are you laughing at-you are laughing at yourself"- - you have no substantive arguments to answer my comments, you use invectives and stupid responses—-see comments on other posts. [X: Z kogo się śmiejecie—z samych siebie się śmiejecie" — nie macie żadnych merytorycznych argumentów żeby odpowiedzieć na moje uwagi to stosujecie inwektywy i głupie odzywki—patrz komentarze przy innych postach.]

Y: 'substantive' - more comments, more. The more the better. You only show what intellectual mediocrity and moral degenerates are the people you represent. This is disgusting. ['merytorycznie' —więcej komentarzy, więcej. Im wiece tym lepiej. Pokazujesz jedynie jakimi intelektualnymi miernotami oraz moralnymi degeneratami sa ludzie, których poglady reprezentujesz. Napawa to obrzydzeniem]

\footnotetext{
${ }^{4}$ The authors preserved the original spelling and punctuation of comments.
} 


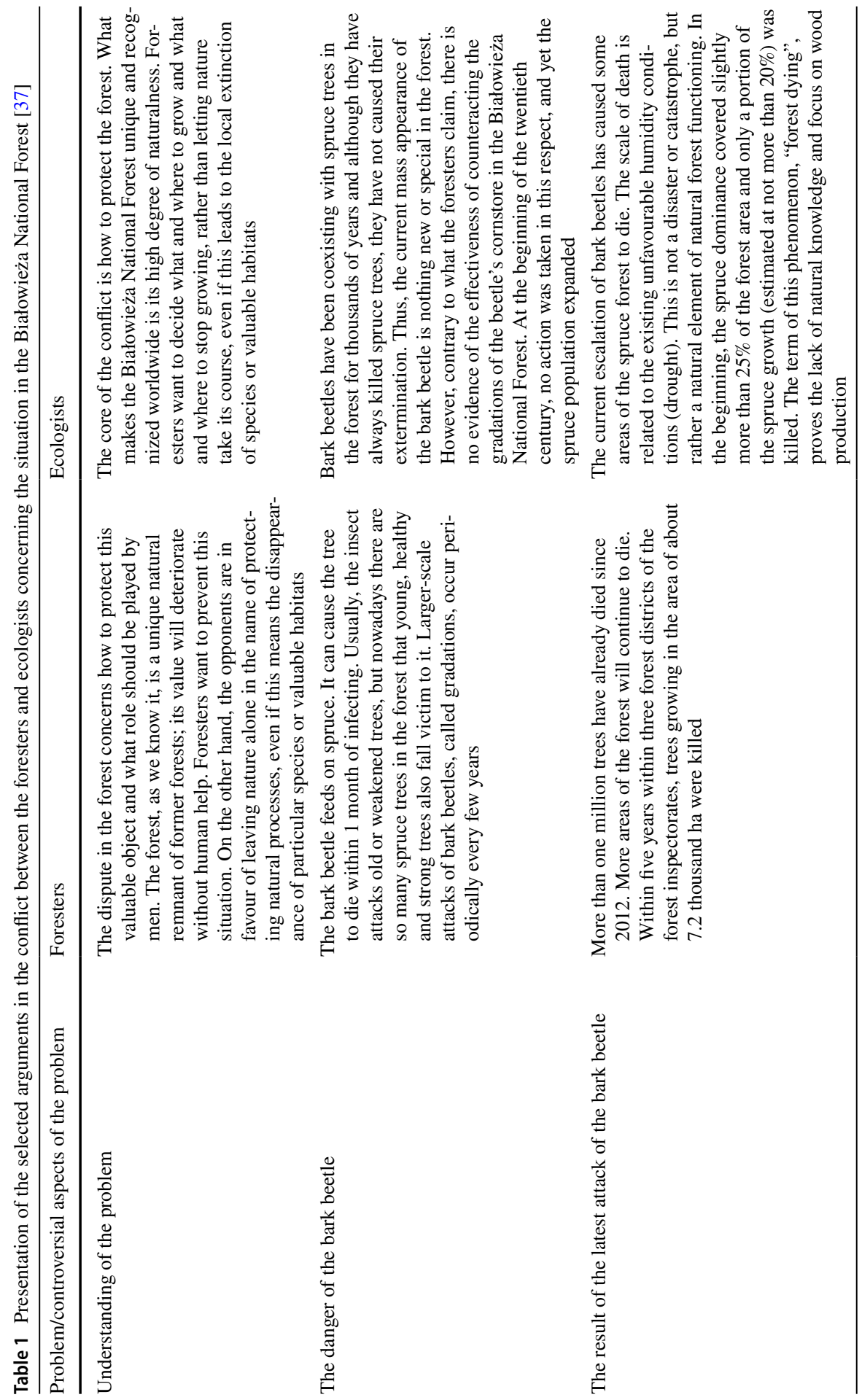




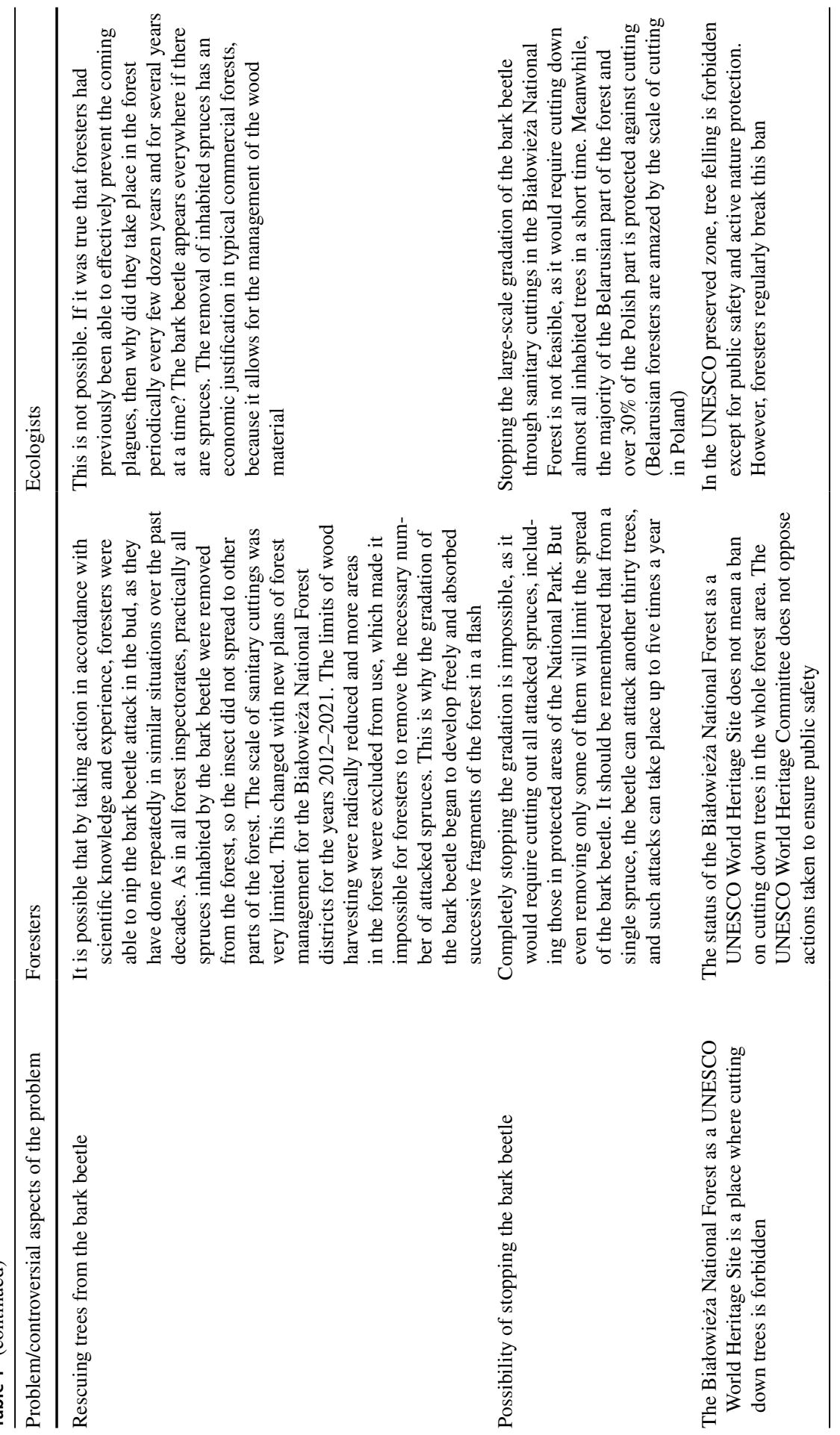


In the comment the irony is applied to insult the opponents. The commentator uses very strong names for the opponents: intellectual mediocrity or moral degenerates. It shows the commentator superiority over the other group. It means that any other belief (not the same as the author of the comment) results in disgust. Moreover, the disgust toward the described group is indicated by the phrase "napawa to obrzydzeniem' (This is disgusting/This fills with disgust).

The second group is the anonymous community of Internet users who often post comments which are very aggressive, explicit and strong in content, while at the same time hiding their real identity behind fictitious nicknames (pseudonyms used on the Internet), names and e-mails.

\subsection{Example No. 2}

Fuck yourself out with your sick theories, and don't forget to take with you the rest of the garbage, German speaking diversioners, 5th column, a bunch of looters, foundations and foreign-funded organizations hostile toward Poland. [A wypierdalajcie już ze swoimi chorymi teoriami, i ne zapomnijcie zabrać ze sobą resztę śmiecia, niemiecko jezycznych dywersantów, V kolumny, bandy grasantów, fundacje i wrogie Polsce a finansowane z zagranicy organizacje...]

The elements of the hate speech are explicitly visible in the first sentence at the very beginning. Also, inside the comments there are insulative invectives toward some groups which reveal the nationalistic view of the author. The third group is a group of people who are deliberately paid to eliminate competition, reduce public support for political opponents, or drive customers to websites. This also involves the use of propaganda, spreading one's own rationale or opinions, and trying to promote them by negating other systems of values, beliefs and rationales.

\subsection{Example No. 3}

Yes, I confirm that there are certain priorities in life and access to work is one of them and in compromise to something one needs to turn a blind eye. I was robbed by PO-PSL on VAT of 250 billion. You screw me driving a car and poisoning the air, screaming that Białowieża Forest dies, and I turn a blind eye. [Tak, potwierdzam, że w życiu są pewne priorytety i dostęp do pracy jest jednym z nich i w kompromisie na coś oko trzeba przymknąć. Okradła mnie PO-PSL na VAT 250 mld. Ty mnie dymasz jeżdżąc samochodem i zatruwając powietrze, krzycząc puszcza Białowieska ginie,a ja przymykam oko.]

This example represents the idea of being deprived of something and because of that one feels that he/she has a permission to do other wrongdoings or act beyond the law. The choice of vocabulary shows that the author of the comments feels frustration and gives himself/herself permission to act in a way he/she likes.

The next examples of comments contain not only some features of hate speech but also different emojis. "Emoji debuted way back in 1999 in Japan with a set of 176 symbols, but exploded in popularity in 2011 when Apple came out with the iPhone 
5. These days, we are up to over 2,600 emoji in the Unicode standard, and at least a few of them can be used to convey threats, depending on one's interpretation." [39]. Wagner et al. [40] state that "Non-verbal cues bring together several aspects of stage directions in these short text messages inclusive of emojis, like in the theatre: (1) the intonation of the voice (i.e. shouting, whispering, affirming, denying, asking a question, suggesting, ironing), (2) facial expressions (i.e. frowning, raising eyes to the sky, widening them, raising one eyebrow higher than the other, squeezing the lips, half-opening them, biting them, lifting a corner of the upper lip), and (3) all the gestures (i.e. having arms crossed, or swinging). Somehow they are substitutes to performance like in the Japanese Noh theatre with specific masks [41] that deliberately exaggerate specific emotions to stimulate imagination of the audience with adequate body language and movement (...)".

The next set of examples containing both verbalized hate speech and emphasis adding emojis will be presented below. It will be conducted on the basis of another hate speech classification focusing on emotions developed by Martins, Gomes, Almeida, Novais, Henriques [42].

The first group includes comments containing emotional load of surprise:

\subsection{Example No. 4}

In his own right. And what rights are these Nutrition of woodworms Take care of your forests in Germany and don't get fucked up into our forests [Na swoich prawach ? A jakie to prawa Żywienie korników Zajmijcie się swoimi lasami w Niemczech i nie wpi...jcie się w nasze lasy]

In the example above emoticons were used as the illustration of the emotions expressed in the statement. Furthermore, a red question mark highlights uncertainty and surprise. The elements of hate speech are explicitly visible in the last sentence where the insulative command is expressed revealing the nationalistic view of the author.

The second group encompasses comments containing an emotional load of disgust:

\subsection{Example No. 5}

Two "wise in a different way"... [Dwóch "mądrych inaczej”... ₹ ]

In the comment the irony is applied to insult the opponents. Moreover, the disgust toward the described group is indicated by the emoticon.

The third group of comments contains an emotional load of anger:

\subsection{Example No. 6}

the crap is replacing the government or doing them against Such "ecologists" and you should not be allowed into the forests without the knowledge of biology! Wherever they appear there is always an ecological and 
natural disaster. That's how ignorant and dumbfounded people take for granted something they have no clue about. Pure bambism of fools! [gówniażeria zastępuje organy Państwa albo robi im wbrew

Tacy "ekolodzy" i Pani nie powinni być wpuszczani do lasów bez zaliczonej wiedzy z biologii! Tam gdzie się pojawiają zawsze następuje katastrofa ekologiczna i przyrodnicza. Tak to jest jak ignoranci i matoły biorą się za coś o czym nie mają pojęcia. Czysty bambizm głupków!]

In the example above the red-faced emoticon symbolising anger represents the emotions of the writer. Additionally in the comment the opponents are presented in a ridiculous way, as people who have no post-school knowledge of biology but consider themselves to be ecologists. By describing the "ecologists" insulative adjectives such as ignorant and dumbfounded are used, simultaneously their stupidity is compared with the naïve stupidity of the heroes form the Disney cartoon.

After having examined the social media platforms described in the initial part of the paper (methodology) used by the groups representing different attitudes to the described conflict, we have identified some linguistic patterns within aggressive and vulgar statements expressed both directly and indirectly. Therefore, our analysis concentrates on detecting whether there are some characteristic patterns of introducing hate statements into the conversation and whether they constitute the acts of cyberbullying. Emojis, apart from using words, are the other important tool that enables to express hate speech. They look sometimes somewhat funny but at the same time can be a very powerful tool to even destroy somebody.

Let us now analyse the indicators of hate speech proposed by Nijakowski [19] in reference to the research corpora.

The first category of features characterising hate speech include excessive generalization of a negative trait such as for instance negative stereotypes of various groups of people including foreign groups [19]. In the analysed texts we find references to Germans, the negative perception of the Holocaust, comparisons of the actions of politicians in Poland to the actions of Hitler and Goebbels. In those examples we mostly have the criticism of the members of one of the Polish political parties that is to say mainly PiS (Prawo i SprawiedliwośćLaw and Justice). The second group of comments refers to the fact that part of the activities of ecological groups including active protests against cutting of infected trees were financed by German associations. This strategy is used in already discussed examples no. 2 and 4.

The second feature which is distinguished in that classification of hate speech encompasses the attribution of particularly negative traits to individuals or groups particularly negative qualities or deeds [19]. In that instance in the majority of cases we may distinguish the expression of absolute lack of acceptance of one of the political parties (already mentioned PiS), condemnation of the Minister of the Environment Professor Jan Szyszko. The comments in general contain irony, reference to the lack of competence and intelligence which from the pragmatic perspective convey a very negative attitude of the speaker to the object and subject of criticism. 


\subsection{Example No. 7}

Szyszko a specialist. Don't make me laugh. The forest has managed and can handle itself without the dumbs [lit. ignoramus] from PIS. [Szyszko fachowiec. Nie rozśmieszajcie mnie. Puszcza sobie radziła i poradzi sama bez pisowskich nieuków.]

In this example the message sender uses the strategy of the opposite sense to convey the meaning of both condemnation and lack of acceptance for the political party and its representative. At the same time the offensive term nieuk 'ignoramus' is used to refer to the lack of competence and knowledge of party members. The pragmatic meaning of the comment is highly pejorative and definitely offensive.

\subsection{Example No. 8}

Szyszko is a worse pest than the bark beetle!!! Animal and tree killer!!! [Szyszko to gorszy szkodnik od kornika!!! Morderca zwierzat i drzew!!!

In this example the message sender uses the metaphor which is typical of the first category of hate speech and in fact expresses dehumanization [19]. The politician is degraded as much as possible as he is claimed to be worse than the insect consuming the forest. In general we must remember that the symbolic meaning of insects is very specific in the European culture. In general they are beings which are considered the least important, not worth caring for, disgusting, arousing revulsion, requiring destruction, simply dangerous pests which should be exterminated. Even the biblical references to insects reveal that they are considered as beings of the lowest importance whose needs may frequently be completely ignored. Therefore the comparison of the Minister of Environment to something worse than the insect is highly degrading and definitely represents the hate speech. It is especially visible when we analyse the second part of the statement where he is called the murderer of trees and animals. The usage of the term, which in general refers to the process of killing people, is in fact the process of personification of trees and animals. So the comment consists of two strategies: the dehumanisation of a person which is even stronger as it is contrasted with the personification of trees and animals. Those two opposites construe the contrast degrading the person and stressing the rights of trees and animals. As it has already been pointed out that statement is a mixture of category two and three of hate speech typology developed by Nijakowski [19].

The third category includes the usage of offensive vocabulary (such as vulgarisms), dehumanization (such as analogies and metaphors) [19]. The process of dehumanisation involves animalisitation and bestialisation of politicians. We should stress here that the surname of the Minister of Environment sounds very similar in Poland as the noun szyszka which means 'cone'. Therefore the strategies used by multiple message senders include various word plays with the surname and the noun. We find suggestions to burn the Minister the same way as we can burn cones. There are also references to turning him to ashes and enriching the soil with his 
charcoaled body. There are also even stronger suggestions that the body of the Minister may be profitably used to fertilise the soil the same way as manure. The word plays also involve creative word formation with the surname of the Minister e.g. the term Homo sapiens is transformed skilfully by resorting to the phenomenon of homophony of the part Homo and the Polish vulgarisms cham 'boor'. The coined term is degrading for the whole species encompassing human beings who contributed to the degradation of the environment or who are, in the opinion of the author, too stupid to understand important but basic processes taking place on the planet Earth.

\subsection{Example No. 9}

Like a bark beetle, a pine cone and szyszko are an element of nature and the nature will cope with them, just dung for the earth. First szyszko, then the cones and bark beetles, unless this process is disturbed by some atomic fire and the earth turns to ashes, then pine trees will grow on the ashes, first as mutants without cones. As in Chernobyl and BOORsapiens will be gone! [Szyszka i szyszko to tak jak kornik element natury i przyroda sobie z nimi poradzi, poprostu gnój dla ziemi. Najpierw szyszko, później szyszki i korniki, no chyba że zakłuci ten proces atomowy pożar i ziemia zmieni się w popiół, to na popiołach wyrosną sosny,na początek jako mutanty bez szyszek. Jak w Czarnobylu i CHAMOsapiens już nie będzie!]

The degrading of the minister is stressed by the fact that his surname starts with a small letter as if it was a common noun not a proper name which requires the initial capital letter. The strategy is repeated twice. Taking into account that the author uses capital letters for the proper noun Chernobyl and to give extra emphasis, this consistent spelling of the surname must be considered a consciously adopted strategy of humiliation and degradation.

The example presented below is the expression of frustration of the speaker caused by the heavy criticism of the Minister of Environment who at the moment of being criticised is dead and cannot defend himself. The frustration is expressed by very vulgar and offensive idiomatic expression chuj wam w dupe 'fuck you, fuck your ass' and the pejorative and polysemous reference to the left-wing politicians lewak (a pejorative noun referring to an extreme leftist).

\subsection{Example No. 10}

Professor Szyszko was right with the Forest. We have it black on white. Hounded, abused. He is no more here today. But I can tell them: fuck the leftwingers in their asses. Regards. [Profesor Szyszko miał rację z Puszczą. Mamy czarno na białym. Zaszczuty, poniewierany. Dzisiaj już Go nie ma. Ale ja im mogę powiedzieć: chuj wam w dupę lewaki. Pozdrawiam.]

The last comment analysed in that category contains the animalisation in the form of comparison. The comparison is negative, expresses the lack of competence and 
knowledge of the Minister of the Environment. At the same time the second part of the comment composed of the rhetoric question and the answer to the question is to prove the bestiality of the Minister of Environment by showing his unethical behaviour when conducting hunting. The example provided is difficult to verify by persons reading the article. It requires the knowledge of the Polish hunting system without which the majority of speakers may not realise that it is punishable in Poland to shoot at birds that are not in the air (ducks sitting on water or partridges closed in cages). Even the species is not the one, the minister went to hunt for. What is more, the controversies actually referred to the participation of the minister in a hunt on a completely different species of birds (that is to say pheasants). So the author of the comments supports his rhetoric on unverified gossip, rumours and even fails to provide the facts.

\subsection{Example No. 11}

Szyszko is such a forester as a pig is a stallion. Do you still remember what a good hunter he turned out to be? He can shoot dead with his friends 500 caged partridges! [Z Szyszki jest taki Leśnik jak ze świni ogier. Pamiętacie jeszcze jakim dobrym myśliwym się okazał? Potrafi z kumplami 500 kuropatw ustrzelić jeszcze w klatkach!] (Article)

The fourth category encompasses various modes of expression of disregard, questioning the custom of respect. Such messages patronise and show superiority of the message sender over the criticised person or group. The following example contains several strategies of expressing disapproval and hatred. First of all, there is a reference to the lack of wit/wisdom of the speaker. The speaker is considered as a person who is not of sound mind and memory. The next three sentences are rhetorical questions which actually are references to issues of the ethics and deeds that are condemnable. Once again, the speaker fails to base his rhetoric on the merits. His view is stereotypical and the arguments that are presented are taken out of the context in which there were used. In turn, the next paragraph contains offensive vocabulary, and a very strongly degrading comparison of the actions of the criticised political party to Hitler, Goebbels and the fascist propaganda. It should be stressed here that the comparison is extremely pragmatically burdened taking into account the genocide of Polish Jews and Poles during the Second World War. Finally, the author ends up with the irony loaded exclamation.

\subsection{Example No. 12}

Marek Krzyszton You are totally crazy. How can you defend the evil that Szyszko has inflicted to the Forest? How can you not know that these hundreds of hectares of felled trees were "harvested" for profit? How can you not remember that Szyszko wanted to legalize the bison and cormorant hunting? 
Beetroot, blind dilettante, which is able to turn a blind eye to all the subordinates of the party with which it sympathizes. They treated you the same way as Hitler, Goebbels and the remaining fascist propaganda gutter treated the German people in the 1930 s.

Well done stupidity both before and after the damage!

[Marek Krzysztoń Jesteście totalnie trzepnieci. Jak można bronić tego zła, które Puszczy wyrządził Szyszko? Jak można nie wiedzieć, że te setki hektarów wyciętych drzew ,,pozyskano” w celach tylko zarobkowych? Jak można nie pamiętać o tym, że Szyszko chciał legalizacji odstrzału żubrów i kormoranów?

Buraczane, ślepe dyletanctwo, które jest w stanie przymknąć oko na wszystkie podelstwa partii z którą sympatyzuje. Zrobiono z was to samo co w latach 30-tych z narodem niemieckim zrobił Hitler, Goebbels i pozostały faszystowski rynsztok propagandy.

\section{Brawo głupoto zarówno przed jak i po szkodzie!]}

The fifth category encompasses catalogues and lists exposing "Jews" [19]. This category has not been found in the analysed corpus.

The sixth category focuses on the object of hatred. That type of hate speech stigmatises the object of criticism or social groups. In general on the one hand one can argue that the belongingness to an occupational group or a political party is not a matter of choice but at the same time we can claim that being a member of a given religion or denomination is a matter of choice. If we assume that the belongingness to a given religious denomination or political party is based on faith, ideals and conviction related factors, we may analyse the criticism of politicians and political parties in that category of hate speech. Though at the same time it must be assumed that nationality, ethnic origin, race are definitely beyond someone's choice whereas religion and political convictions are a matter of choice though each human being has got a constitutional right in democratic states not to be discriminated against because of his or her religious or political choices as long as they are lawful. At the same time it may be debatable whether the profession which is sometimes acquired as early as vocational secondary education can be easily changed taking into account the job market opportunities.

The next two examples contain the word play with the surname of the Minister of Environment based on the term szkodnik 'vermin' which if translated literally would mean cone-vermin. The ruling parties accused of corruption. At the same time the representatives of the Catholic church are presented negatively as well. A very offensive term swotocz 'scum' borrowed from the Russian language in the communist period is used to degrade the criticised persons.

\subsection{Example No. 13}

@ dlaPuszczy \#puszczabialowieska needs all the help it can get in protection from \#Szyszkodnik \#Szyszko to remain a natural forest, not a wood factory. 
The HQ of the corrupt state forest agency in \#Warsaw is under occupation from activists now. Up the rebels! $!^{5}$

The scum supporting \# Cone.vermin @ jkardanowski and \# Rydzyk will get mad. (Twitter) [No to swołocz od \#Szyszko.dnika@jkardanowski.ego i \#Rydzyk.a się wścieknie.][ [y

To sum up we have observed the hate speech used by the message senders both criticising the foresters and ecologists. Despite the fact that in the majority of cases the analysed materials come from moderated sources, the markers of hate speech still may be identified and the escalation of anger is clearly visible in the dialogues in which participants engage.

In general, when analysing the functions of both monologues and dialogues we can point out to the following message functions:

1. A provocative function,

2. A humiliating and degrading function,

3. A purgatory function,

4. An objection-raising function,

5. A patronizing function. (cf. also [43-46]).

The provocative function in the first place serves the purpose of catching the reader's attention and making him engage in cross-fire of information exchange. It may be the provocation aiming at getting "likes" and support comments as well as "dislikes" and opponents' comments.

\subsection{Example No. 14}

Marek Krzyszton What is this gibberish ??? I have not realized that this proPIS party side of the narrative is as insolent and simply as stupid as a shoe. Normally an orgasm of stupidity.

[Marek Krzysztoń Co to za bełkot??? Nie zdawałem sobie sprawy z tego, że ta propisowska strona narracji jest aż tak bezczelna i zwyczajnie jak but głupia.

Normalnie orgazm głupoty

The provocative effect is achieved by the reference to the sexual sphere of human life that is to say orgazm 'orgasm' which is used in reference not to a human being but the abstract noun gtupota 'stupidity'. There is the emphasis added by using the adjective 'stupid' and the noun 'stupidity' in close vicinity. What is more, the provocateur statement is also encoded in the phrase "pro-PiS party side of the narrative" which suggests that the opponent is not objective in formulating arguments, he or she is politically biased.

5 This comment was written originally in English. It is not translation from Polish into English. 
The humiliating and degrading function encompasses the instances of cyberbullying. Such messages usually contain offensive language or even vulgarisms. They refer to the low IQ of the interlocutor, his deficient knowledge, etc. Furthermore, the humiliating and degrading function is realized by the usage of offensive language without any merit-based arguments supporting the expressed criticism and disapproval—cf. example below. In this example we have three persons engaged in the discussion. A, B and C. They use their real life names and surnames. The arrow indicates who sends the message to whom when commenting on previous posts. The arrow indicates the direction of communication. Vulgarisms and offensive words are bolded.

\subsection{Example No. 15}

$\mathrm{A} \rightarrow \mathrm{B}$ Moron - this is the best word to describe your mentality man (in addition boor) 8$\}$ [Debil-to najlepsze słowo na określenie twojej mentalności człowieku (w dodatku cham) B.

$\mathrm{C} \rightarrow \mathrm{A}$ Dear Sir. You are talking fucking nonsense. 8000 ha of spruces killed. Reed cutter enters. When the fucking fire starts, then the bisons will grow wings or will they burn alive? Fuck yourself into this empty head. [Panie szanowny. Pierdolisz pan jak potłuczony. 8000 ha świerków zabite. Trzcinnik wchodzi. Jak sie zacznie jarac to żubry skrzydeł dostaną czy spłoną żywcem? Jebnij sie w ten pusty łeb.]

$\mathrm{A} \rightarrow \mathrm{C}$ A chemist from the fuel industry wants to instruct a forester-a circus! You're the one who's fucking about something you don't have an idea about. (1.30 [Chemik z branży paliw chce pouczać leśnika-cyrk! To pan

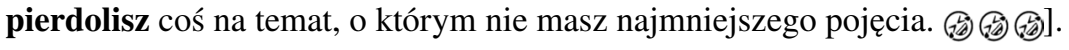

$\mathrm{C} \rightarrow \mathrm{A}$ It just so happens that I'm not just a chemist. And you sir are talking fucking nonsense. Plaster the wings to bisons. [Tak się składa że jestem nie tylko chemikiem. A szanowny Pan pierdoli jak potłuczony. Sztukuj skrzydła żubrom].

$\mathrm{B} \rightarrow$ A Guy, don't strain yourself so much, because you veins will fuck out, you think "man" that you have eaten reason, because you have defended the killing of the Białowieża Forest; for the first few years before I became a forester, I worked in BULiGL [the Office of Forest Management and Forest Surveying], I don't know the forester whether you know what this abbreviation stands for, what it is, and already at that time I had contact with the so-called "ecologists" of your kind, in places where they stayed in the forest, dirty sanitary napkins, condoms and other dumpster remained, so being a forester, I chased this trash out of the forest. (i) (i) tak bardzo, bo ci żyłka jebnie, myślisz „,człowieku”, że rozumy pozżerałeś, bo bronisz uśmiercania Puszczy Białowieskiej, przez pierwsze parę lat, zanim zostałem leśniczym, pracowałem w BULiGL, nie wiem leśniku czy 
wiesz co ten skrót znaczy, z czym to się je, i już wówczas miałem styczność z "ekologami" pańskiego pokroju, tam gdzie przebywali w lesie pozostawały brudne podpaski, prezerwatywy i inne śmietnisko, dlatego będąc leśniczym,

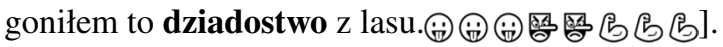

The offensive function is also achieved by comparing people to trash-dehumanizing them. The usage of offensive emojis aims at adding extra emphasis to the comments.

The purgatory function in general serves the purpose of releasing extreme and overwhelming emotions. The emotions released are negative. They may reveal verbal aggression. Very frequently, they also reveal frustration, powerlessness and despair.

\subsection{Example No. 16}

Several times this fall I went to the forest to pick mushrooms, where my Dad used to go. My heart ached when instead of mushrooms I saw in almost every place, sad, dry, quiet.... dead forest..... Nothing but maggots and wild raspberries.... in which there is no self-seeding and ticks in the dry grass. As a result, I picked mushrooms, but only in the vicinity of Dubicze Cerkiewne. I postulate to plough activists.... how can you hurt this forest for material or ideological benefits... only a fool can't see it....

[Kilkakrotnie tej jesieni wybrałam się na grzyby, w miejsca gdzie kiedyś chodził mój Tato. Serce mnie bolało kiedy zamiast grzybów prawie w każdym z miejsc zobaczyłam, smutny, suchy, cichy....martwy las..... Dookoła nic tylko płazowiny i dzikie maliny....w których nie widać żadnej samosiejki i kleszcze w wyschniętej trawie. W rezultacie grzybów nazbierałam i owszem, ale dopiero w okolicach Dubicz Cerkiewnych. Postuluję zaorać aktywistów.... jak można dla korzyści materialnych bądź ideologicznych tak krzywdzić ten las.... tylko głupiec tego nie widzi....]

At the first glance that comment looks innocent and regretful. But the last sentence expresses hatred directed at persons who contributed to the destruction of the forest though expressed in relatively mild manner.

The objection-raising function serves the purpose of expressing a different worldview, an objection to some action, someone else's point of view.

\subsection{Example No. 17}

Anonimowy31 grudnia 2010 22:42

Happy New Year 2011 for people with a healthy approach to nature. And regarding the title of the text "Let 2011 bring a national park for the entire Białowieża Forest"- of course, God Defend! And for the creators of this blog-people, think about it !!! Do not follow this way !!! There is always time to convert and stop destroying the nature we have in the Forest with the stupid 
conservation that you have in your mind... A bit of moderation and common sense in this New Better 2011. Not everything in this world of yours is for bugs and mushrooms :)

[Wszystkiego najlepszego w Nowym Roku 2011 dla ludzi ze zdrowym podejściem do przyrody. A odnośnie tytułowego tekstu "Niech rok 2011 przyniesie park narodowy dla całej Puszczy Białowieskiej”-to oczywiście Broń Boże! A dla twórców tego bloga-ludzie opamiętajcie się!!! Nie idźcie tą drogą!!! Zawsze jest czas żeby się nawrócić i nie niszczyć przyrody jaka mamy w Puszczy głupią ochroną, jaką macie w swych głowach... Trochę umiaru i zdrowego rozsądku w tym Nowym Lepszym 2011 Roku. Nie wszystko na tym waszym świecie jest dla robaczków i grzybków:)]

However, the comment above cannot be classified as the example of the hate speech. In general, longer opinions were usually merit-based, contained scientifically based arguments and were convincing. At the same time in the majority of cases they could not be classified as the hate speech even if they contained severe criticism. Sometimes they contained some load of hatred but skillfully veiled. But we can also find examples condemning stupidity in a very ironic manner. Such examples are border cases in the case of which it is difficult to decide whether a thin line between criticism and hatred has been crossed or not.

\subsection{Example No. 18}

And you from 12:36, a specialist in the conservation of log species, have you gained your knowledge from the place of power using a pendulum? Drop a bomb on your home-you will have an imitation of a natural meteor impact, and what new species will appear!

[A ty z 12:36, specjalista od ochrony gatunkow zrębowych to wiedzę przyrodniczą czerpałeś wahadełkiem z miejsca mocy? Zrzuć sobie na swoją siedzibę bombę_-będziesz miał imitację naturalnego uderzenia meteorytu, a jakie nowe gatunki się pojawią!]

The patronising function serves the purpose of informing someone about facts. Nevertheless, it is usually not effective as far as its education function is concerned. It usually arouses the feeling of contempt, objection, or even rebellion. It is similar to the technique used by the parent scolding the child. However, in the event of interlocutors who perceive themselves as being right and tormented by justified anger usually they are not efficient communication techniques. They lack a persuasive force even if they are merit-based. 


\subsection{Example No. 19}

$\mathrm{A} \rightarrow \mathrm{B}$ Yes, I read, and I think, of course, you have knowledge, but it stopped at the time when you graduated from your university (i.e. distant Polish People's Republic times) Fortunately, no one at the Faculty of Forestry at the Warsaw University of Life Sciences (SGGW) is telling such unconvincing stories of the forest grandfather.

[Tak czytam, i myślę że oczywiście wiedzę macie, ale zatrzymała się ona na czasach kiedy ukończyliście swoje uczelnie (czyli głęboki PRL) Całe szczęście obecnie nikt na wydziale leśnym SGGW nie opowiada takich wątłych opowieści leśnego dziadka].

\subsection{Example No. 20}

$\mathrm{B} \rightarrow \mathrm{A}, \mathrm{C}$, etc. Probably these nails are not only in your leg-but also in your head? $\mathrm{C}$ listen to me, I feel like after the introduction of Christianity to the Polish lands-I am also trying to convert as the missionary. But it is difficult to make the foresters get rid of paganism and ignorance

[chyba nie tylko w nodze te gwoździe-również w głowie? Jan Kucharzyk ja się tu czuje jak po wprowadzeniu chrześcijaństwa na ziemie Polskieteż staram się jak ten misjonarz nawracać. Ale trudno oderwać leśników od pogaństwa i tej ciemnoty].

Two examples presented above can hardly be classified as the hate speech despite some offensive content. It is due to the fact that they are not loaded with hatred. Though they are irreverent.

\section{Concluding Remarks}

As the analysed messages have been posted on social media which are censored by blog and site moderators, the number and strength of vulgarisms that frequently serve the purpose of adding extra emphasis, shocking, offending or expressing habitual mode of speech are very limited. That enables us to draw the conclusion that the censoring of posts prevents the escalation of aggression which has been observed when analysing posts against foresters [1].

The question may be posed here whether the freedom of speech should be exercised freely and without any constraints or whether the moderators should be obliged to establish rules of commenting to prevent the escalation of verbal aggression and encourage merit-based exchanges of opinions. The comparison of the research material on the Białowieża National Forest dispute and sites against hunters leads to the conclusion that sites open to public should be monitored in respect of the language, and in the event of the occurrence of offensive, vulgar and humiliating messages, the commenting persons should be educated that such verbal behaviours are not proper. 
In the initial period, the interlocutory techniques in general encompassed resorting to first posting a verbal provocation and waiting for some reaction. Then, a provocative monologue would be replaced with a dialogue. What is more, the more heated the monologue would be, the more aggressive the replies were. At that period of time, when the consequences of inaction (not cutting the trees infected with the beetle) were not known and visible, both sides of the conflict adopted the same techniques of argumentation. The longer, more elaborate posts were much more meritbased than short ones. They very frequently may be classified as criticism, presenting conscious opinions, etc. The shorter posts in turn frequently contain offensive language, even hate speech.

The second stage of communication actually in the majority of cases involves foresters and people who have supported the cutting off trees infected by the beetle. It is the stage which has started the moment the consequences of the lack of human intervention occurred. What is characteristic of this stage is that the foresters and supporters of foresters actually deliver monologues about the actual state of the Białowieża National Forest, the degradation and danger caused by dead trees. They express their outrage, frustration and despair. They offend their past opponents who do not interact with them and who refrain from engaging in a discussion.

In conclusion, the analysed corpus consisted of texts with national hate speech features such as utterances expressing hatred of national political parties and their representatives, Catholics and Catholic celebrities, professional groups that is to say state forests employees. After having examined the selected social media platforms used by the groups representing different attitudes to the described conflict (including Facebook, Twitter etc.), we have identified linguistic patterns within aggressive and vulgar statements expressed both directly and indirectly. The main strategies of releasing anger include:

(i) Offensive and sometimes vulgar language, though due to the fact that most of the sources were moderated the most vulgar comments were quickly deleted from websites. As a consequence it is not possible to assess the scale of vulgarism usage and their emotional hatred load.

(ii) Irony, based on apparently supporting one side of the conflict in a deliberately ridiculous manner. The statements very frequently lampoon the lack of deep domain knowledge or are patronizing. They often stigmatize stupidity.

(iii) Rhetorical questions aiming mostly at proving that the other side of the conflict is stupid, ignorant or barbaric, uncivilised.

(iv) Using analogies and metaphors.

As far as Facebook comments are concerned, we can distinguish three types of them: short (insulting), moderate (intelligent insulting), elaborative (with facts, with references to other research but sometimes with veiled insult).

Some regularity is also noted, the shorter the comment, the more vulgar and hateful it is.

1. One-verse comments usually contain profanity, these are offensive comments, and sometimes they include threats, 
2. Paragraphs are also characterized by vulgarity, but sometimes there is some meritbased content in them, sometimes also comments are essential where the insult is veiled,

3. Elaborative comments are usually well-prepared, with a limited dose of offensive language which is mostly hidden.

In the case of the analysed article less than $10 \%$ of comments were offensive.

Moreover, the following types of hate speech have been identified:

1. Excessive stereotyping generalization of a negative trait;

2. Attribution of particularly negative traits or deeds to groups or their representatives;

3. Offensive vocabulary, including: dehumanization, animalization and bestialisation;

4. dDsregard, disrespect, patronising treatment, superiority;

5. Stigmatization of the object of hatred.

Definitely, persons commenting online believe they are surrounded by more likeminded people in cyberspace than in real-world. As already mentioned they unite and feel free to express their opinions online, minimizing the so-called spiral of silence. Acting as a member of a group, they feel they are right because they share the views expressed by people who are wise, knowledgeable, well-educated. At the same time, the analysis of the linguistic quality of comments from the perspective of idiolects reveals that the most vulgar and aggressive comments are expressed by both well educated and non-educated people. Additionally, the outburst of aggression, leads to the aggressive response and in consequence the escalation of aggression may be observed in dialogues held online. Both sides of the conflict resorted to hate speech. Though, sophisticated, veiled criticism is characteristic of educated people who can skilfully hide and control their hatred. There is a thin line between the acceptable criticism, freedom of speech and the hate speech.

Open Access This article is licensed under a Creative Commons Attribution 4.0 International License, which permits use, sharing, adaptation, distribution and reproduction in any medium or format, as long as you give appropriate credit to the original author(s) and the source, provide a link to the Creative Commons licence, and indicate if changes were made. The images or other third party material in this article are included in the article's Creative Commons licence, unless indicated otherwise in a credit line to the material. If material is not included in the article's Creative Commons licence and your intended use is not permitted by statutory regulation or exceeds the permitted use, you will need to obtain permission directly from the copyright holder. To view a copy of this licence, visit http://creativecommons.org/licen ses/by/4.0/.

\section{References}

1. Matulewska, Aleksandra, and Dariusz J. Gwiazdowicz. 2020. "I Would Kill the Director and Teachers in the School" Cyberbullying of Hunters in Poland. International Journal for the Semiotics of Law. https://doi.org/10.1007/s11196-020-09723-8. 
2. Matulewska, Aleksandra, and Dariusz J. Gwiazdowicz. 2020. Cyberbullying in Poland: a case study of aggressive messages with emojis targeted at the community of hunters in urbanized society. Social Semiotics 30 (3): 379-395. https://doi.org/10.1080/10350330.2020.1731194.

3. Baruah, Trisha Dowerah. 2012. Effectiveness of Social Media as a tool of communication and its potential for technology enabled connections: A micro-level study. International Journal of Scientific and Research Publications Volume 2, Issue 5. http://www.ijsrp.org/research_paper_may2012/ ijsrp-may-2012-24.pdf. Accessed 12 January 2020.

4. Boyd, Danah, and Nicole B. Ellison. 2008. Social Networking Sites: Definition, History, and Scholarship. Journal of Computer-Mediated Communication 13 (1): 210-230.

5. Manning, J. 2014. Social media, definition and classes of. In Encyclopedia of social media and politics, ed. Kerrick Harvey, 1158-1162. Thousand Oaks, CA: Sage.

6. Ding, Lin, and Hua Hu. 2013. Feature Analysis of the Social Media. International Workshop on Computer Science in Sports: 186-190.

7. Akram, Waseem, and Rekesh Kumar. 2017. A Study on Positive and Negative Effects of Social Media on Society. International Journal of Computer Sciences and Engineering 5 (10): 347-354.

8. Cynthia, Van Hee, Gilles Jacobs, Chris Emmery, Bart Desmet, Els Lefever, Ben Verhoeven, Guy De Pauw, Walter Daelemans, and Ve'ronique Hoste. 2018. Automatic detection of cyberbullying in social media text. PLoS ONE 13(10): 1-22. https://doi.org/10.1371/journal.pone.0203794. Accessed 12 January 2020.

9. Schulz, Anne, and Patrick Roessler. 2012. The spiral of silence and the Internet: Selection of online content and the perception of the public opinion climate in computer-mediated communication environments. International Journal of Public Opinion Research 24 (3): 346-367.

10. Noelle-Neumann, Elisabeth. 1974. The spiral of silence a theory of public opinion. Journal of Communication, 24(2): 43-51. https://doi.org/10.1111/j.1460-2466.1974.tb00367.x. Accessed 30 June 2020.

11. Woong, Yun Gi, and Sung-Yeon Park. 2011. Selective posting: Willingness to post a message online. Journal of Computer Mediated Communication 16 (2): 201-227.

12. Ghada M. Abaido. 2019. Cyberbullying on social media platforms among university students in the United Arab Emirates. International Journal of Adolescence and Youth, https://doi. org/10.1080/02673843.2019.1669059. https://www.tandfonline.com/doi/pdf/10.1080/02673 843.2019.1669059?needAccess=true. Accessed 12 January 2020.

13. Cambridge Online Dictionary. Hate Speech. https://dictionary.cambridge.org/us/dictionary/english/ hate-speech. Accessed 24 January 2020.

14. Nockleby, John T. 2000. Hate Speech. In Encyclopedia of the American Constitution, eds. Leonard W. Levy and Kenneth L. Karst, vol. 3. (2nd ed.), 1277-79. Detroit: Macmillan Reference US.

15. Chris Cuomo. 2015. CNN's Chris Cuomo: First Amendment doesn't cover hate speech. https:// www.politifact.com/factchecks/2015/may/07/chris-cuomo/cnns-chris-cuomo-first-amendmentdoesnt-cover-hate/. Accessed 20 January 2020.

16. Venice Commission. 2008. Analysis of the Domestic Law Concerning Blasphemy, Religious Insult and Inciting Religious Hatred in Albania, Austria, Belgium, Denmark, France, Greece, Ireland, Netherlands, Poland, Romania, Turkey, United Kingdom on the Basis of Replies to a Questionnaire. Council of Europe. https://www.venice.coe.int/WebForms/documents/?pdf=CDL-AD(2008)026-e. Accessed 20 January 2020.

17. RADAR Flyer 2015.

18. Weber, Anne. 2009. Manual on hate speech. Strasbourg Cedex: Council of Europe Publishing.

19. Nijakowski, M. 2008. Mowa nienawiści w świetle teorii dyskursu. Toruń.

20. Cyber Bullying Law and Legal Definition. USLegal. https://definitions.uslegal.com/c/cyber-bully ing/. Accessed 20 January 2020.

21. Diaz, Fernando L. 2016. Trolling \& the First Amendment: Protecting Internet Speech in the Era of Cyberbullies \& Internet Defamation. University of Illinois Journal of Law, Technology \& Policy: 135-160.

22. Dagan, Maeve. 2014. 5 facts about online harassment. https://www.pewresearch.org/facttank/2014/10/30/5-facts-about-online-harassment/. Accessed 23 March 2020.

23. Byrne, Elizabeth, Judith A. Vessey, and Lauren Pfeifer. 2017. Cyberbullying and Social Media: Information and Interventions for School Nurses Working With Victims, Students, and Families. The Journal of School Nursing. 34 (1): 38-50. https://doi.org/10.1177/1059840517740191. 
24. Fischer, Douglas. 2010. The Daily Climate. "Cyber Bullying Intensifies as Climate Data Questioned". https://www.scientificamerican.com/article/climate-cyber-bullying/. Accessed 23 March 2020.

25. Browning, Dominique. 2012. When Grownups Bully Climate Scientists. Bullying is thuggish no matter who is doing it. So why are grown adults engaging in it? Time. https://ideas.time. com/2012/04/10/when-grownups-bully-climate-scientists/. Accessed 23 March 2020.

26. Habib, Ben. 2011. Bullying climate change scientists. https://www.latrobe.edu.au/news/artic les/2011/opinion/bullying-climate-change-scientists. Accessed 23 March 2020.

27. An explanation of the growing phenomenon of cyberbullying. National Crime Prevention Council. https://www.ncpc.org/resources/cyberbullying/what-is-cyberbullying/. Accessed 12 January 2020.

28. Ybarra, Michele L., and Kimberly J. Mitchell. 2004. Online Aggressors/Targets, Aggressors, and Targets: A Comparison of Associated Youth Characteristics. Journal of Child Psychology and Psychiatry and Allied Disciplines 45: 1308-1316. https://doi.org/10.1016/j.chb.2011.09.004.

29. Law, D.M., J.D. Shapka, S. Hymel, B.F. Olson, and T. Waterhouse. 2012. The changing face of bullying: an empirical comparison between traditional and internet bullying and victimization. Computers in Human Behavior 28: 226-232.

30. Patchin, Justin W., and Sameer Hinduja. 2006. Bullies Move Beyond the Schoolyard: A Preliminary Look at Cyberbullying. Youth Violence and Juvenile Justice 4 (2): 148-169.

31. Bo, Xu, Xu Zhengchuan, and Dahui Li. 2016. Internet aggression in online communities: a contemporary deterrence perspective. Info Systems Journal 26: 641-667.

32. Cyberprzemoc w polskim Kodeksie karnym od 6 czerwca. 2011. http://www.kancelariabialic.pl/ web.n4?go=62. Accessed 11 March 2020.

33. Olszewska, Wioletta. 2010. Paragraf na stalkera. Na wokandzie. http://nawokandzie.ms.gov.pl/ numer-3/wokanda-3/paragraf-na-stalkera.html. Accessed 20 January 2020.

34. USLegal https://definitions.uslegal.com/c/cyber-bullying/. Accessed 12 January 2020.

35. Monitor Leśny. http://www.forest-monitor.com/pl/problem-puszczy-bialowieskiej/. Accessed 22 January 2020.

36. World Heritage Center. UNESCO. http://whc.unesco.org/en/list/33. Accessed 22 January 2020.

37. Gurgul, Aleksander. 2017. Puszcza w unijnym trybunale. Gazeta Wyborcza 14 lipca 2017: 9, https ://www.twojapogoda.pl/wiadomosc/2017-10-11/spor-o-puszcze-bialowieska-kto-ma-racje-zobacz-isam-zdecyduj/. Accessed 22 January 2020.

38. Szymczak, E. 2015. Hejting jako przykład współczesnego zagrożenia w przestrzeni społecznej [Hating as an Example of Contemporary Threats in Social Space]. Studia Edukacyjne nr 37: 91-107. Poznań: Adam Mickiewicz University Press. ISBN 978-83-232-2967-4. ISSN 1233-6688. https:// doi.org/10.14746/se.2015.37.7.

39. Hinduja, Saamer. 2018. Emoji as Threats in Student Messages and Social Media. Cyberbullying Research Center. https://cyberbullying.org/emoji-as-threats-in-student-messages-and-social-media. Accessed 8 August 2019.

40. Wagner, Anne, Sarah Marusek and Wei Yu. 2020. Emojis and Law: Contextualized Flexibility of Meaning in Cyber Communication. Social Semiotics (Forthcoming).

41. Pellecchia, D. 2011. Aesthetics and Ethics in the Reception of Noh Theatre in the West. Ph.D. Thesis: Royal Holloway: University of London. Retrieved from: https://pure.royalholloway.ac.uk/portal/ files/4400190/pellecchia_phd_thesis_corrected.pdf. Accessed 22 January 2020.

42. Ricardo Martins, Marco Gomes, Jose Jóao Almeida, Paulo Novais, and Pedro Henriques. 2018. Hate speech classification in social media using emotional analysis. Conference paper. Conference: 2018 7th Brazilian Conference on Intelligent Systems (BRACIS).

43. Markowski, Andrzej. 2005. Kultura języka polskiego. Teoria. Zagadnienia leksykalne. Warszawa: Wydawnictwo Naukowe PWN.

44. McEnery, Tony. 2006. Swearing in English. Bad Language, Purity and Power from 1586 to the Present. New York: Routledge.

45. Grochowski, M. 2008. Stownik polskich przekleństw i wulgaryzmów. Warszawa: Wydawnictwo naukowe PWN.

46. Mikołajczyk, B. 2008. Wyrażenia znieważające jako leksykalne środki realizacji aktów zagrażających twarzy na przykładzie języka niemieckiego i polskiego. 186-197. http://www.fil. ug.gda.pl/upload/files/176/mikoajczyk.pdf. Accessed 28 December 2010. 
Publisher's Note Springer Nature remains neutral with regard to jurisdictional claims in published maps and institutional affiliations.

\section{Affiliations}

\section{Aleksandra Matulewska ${ }^{1} \cdot$ Joanna Kic-Drgas $^{1} \cdot$ Paula Trzaskawka $^{1}$}

Aleksandra Matulewska

aleksandra.matulewska@gmail.com

Joanna Kic-Drgas

j.drgas@amu.edu.pl

1 Adam Mickiewicz University in Poznań, Poznań, Poland 